\section{Original Research}

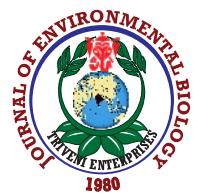

DOI : http://doi.org/10.22438/jeb/41/2(SI)/JEB-01
Journal Home page : www.jeb.co.in $\star$ E-mail : editor@jeb.co.in

\section{Journal of Environmental Biology}

p-ISSN: 0254-8704

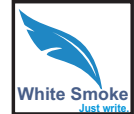

\title{
Preservation and ecology of a living relict shrub in South Caucasus as a eco-genetic heritage from Tertiary: Epigaea gaultherioides (Boiss. \& Bal.) Takht.
}

\author{
M. Ozturk ${ }^{1 *}$, V. Altay ${ }^{2}$, M. Kucuk ${ }^{3}$, E. Altundağ ${ }^{4}$, Z. Severoğlu ${ }^{5}$ and I.E. Yalçın ${ }^{6}$ \\ 'Botany Department and Centre for Environmental Studies, Ege University, Izmir-35040, Turkey \\ ${ }^{2}$ Biology Department, Faculty of Science and Arts, Hatay Mustafa Kemal University, Hatay-31030, Turkey \\ ${ }^{3}$ Sustainable Forest Management Advisor-UNDP, Ankara-06100, Turkey \\ ${ }^{4}$ Biology Department, Faculty of Science \& Arts, Düzce University, Düzce-81620, Turkey \\ ${ }^{5}$ Biology Department, Faculty of Science and Arts, Marmara University, Istanbul-34722, Turkey \\ ${ }^{6}$ Faculty of Engineering and Natural Sciences, Bahcesehir University, Istanbul-34353, Turkey \\ *Corresponding Author Email : munirozturk@gmail.com
}

\section{Abstract}

Aim: Epigaea gaultherioides is an euxine element with a tertiary origin as a relict species facing threat of extinction. In this study, an attempt was made to explore the ecological characteristics by taking into consideration the soil-plant interactions of this taxon.

Methodology : Soil and plant samples were collected and analysed using Kjeldahl, Spectrophotometer, Flame photometer and ICP-OES.

Results : The findings showed that generally grows on sandy and / or clayey soils, of strong acidic nature, non-calcified, non-saline and high in organic matter. The plant samples collected from the study area were rich in iron, aluminium, zinc and nickel; but their percentage in the soils was low.

Interpretation : The findings of this study will assist to better understand the ecological requirements of this relict taxon for its possible future successful conservation programs.

Key words : Eco-genetical heritage, Endemic, Epigaea gaultherioides, Relict, Shrub

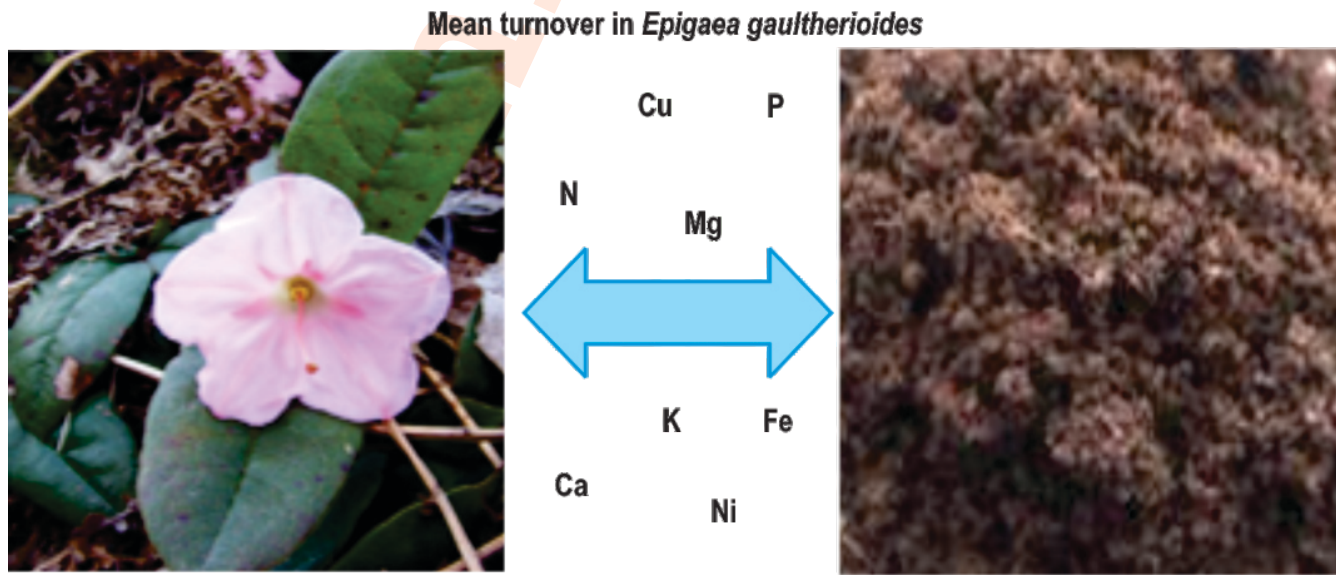

How to cite : Ozturk, M., V. Altay, M. Kucuk, E. Altundağ, Z. Severoğlu and I.E. Yalçın: Preservation and ecology of a living relict shrub in South Caucasus as a eco-genetic heritage from Tertiary: Epigaea gaultherioides (Boiss. \& Bal.) Takht. J. Environ. Biol., 41, 279-284 (2020) 


\section{Introduction}

Colchic region is one of the most important refuges for Tertiary relict biota in western Eurasia (Mai, 1995; Denk et al., 2001). The climate of the area is mild, with evenly distributed high precipitation and lack of winter frosts (Denk et al., 2001). Tertiary relict taxa present here are extant species which showed extensive distribution ranges in the region during different periods of the Tertiary, but are currently confined to small isolated areas (Denk et al., 2001). The relict taxa are mostly disjunctly distributed found in the Iberian Peninsula at the western margin of west Eurasia and in the Euxinian area (northern Turkey, western Georgia) in the East. These taxa also show small disconnected ranges throughout western Eurasia, but some are confined to only one of the potential relict areas of western Eurasia, whose relict nature is deduced from their fossil record only (Denk et al., 2001). The identification of relict populations, or of refugia can prove to be helpful in the conservation of such taxa (El-Bana et al., 2010). In addition to this the naturally gowing rare species or "old rare" species are regarded as endemics and relicts with a narrow range, restricted habitat or small population size (Huenneke, 1991; Aguilar et al., 2008; Šmídová et al., 2011; Wei and Jiang, 2012). There is an urgent need to investigate the history of such populations using evidence from different fields (Pott, 1995; Šmídováetal., 2011).

Despite its ecological value and threatened status, no detailed ecological studies on the current status of Epigaea gaultherioides (Boiss. and Bal.) Takht. in the vulnerable ecosystems have been carried out. In view of the above, the present study provides insights into some ecological characteristics of this relict taxon.

\section{Materials and Methods}

Study species: Epigaea has three species each distributed on one of three land masses. Epigaea repens is found broadly in the eastern United States, E. asiatica is found in Japan and nearby islands, and $E$. gaultherioides is found in the Caucasus region of Eurasia (Gillespie and Kron, 2013). The Caucasus region has also been identified as a biodiversity 'hotspot' and possible Pleistocene refugium (Gillespie and Kron, 2013).

E. gaultherioides is an evergreen prostrate dwarf shrub, sharing the habitats, together, with Fagus orientalis and Picea orientalis forests as well as Vaccinium arctostaphylos and different taxa of Rhododendron. It rarely occurs on open northfacing slopes, generally found between $900-2300 \mathrm{~m}$ altitudes in the Northern parts of Turkey, the Caucasus and Georgia (Davis, 1978; Serdar et al., 2010). It is found in the Rize and Artvin provinces in Turkey (northeast Anatolia). The phytogeographical origin of this tertiary relict and rare taxon is presented as Euxine element (Davis, 1978).
Study sites: The plant and soil samples were collected from five different locations in the Northern areas of Turkey. The information on the collection sites is given below:

Location 1: Artvin-Şevvaltepe, Sazlıkdere $1700 \mathrm{~m}$; Location 2: Rize-Ikizdere, Çağırankaya $1850 \mathrm{~m}$; Location 3: Artvin-Murgul, Tiryal Mountain 2000 m; Location 4: Rize-Ikizdere, $2000 \mathrm{~m}$ and Location 5: Artvin-Murgul, Tiryal Mountain $2100 \mathrm{~m}$.

Data analyses: Soil samples were collected from 0-30 cm depth air dried, and sieved using $2 \mathrm{~mm}$ mesh. The physical/chemical characteristics were determined following the methods outlined by Ozturk et al. (1997). The plant samples were also collected during same time, brought to the laboratory, left under direct air on the table, then dried at $80^{\circ} \mathrm{C}$ for $24 \mathrm{hrs}$ and hand crushed. Total nitrogen content was determined by the Kjeldahl method; phosphorus content was estimated spectrophotometerically and total potassium and sodium content by flame photometer (Ozturk et al., 1997). The concentrations of potassium, calcium, magnesium, zinc, iron, copper, nickel, cadmium, lead, cobalt and aluminium were determined in the plant samples as well as the soils supporting the plant by inductively coupled plasma optical emission spectroscopy (ICP-OES) (Ozturk et al., 2017).

Statistical analyses: All calculations were based on parameters of plant species and soil samples. Pearson's correlation statistical analyses was performed using IBM SPSS Statistics 20 software. Statistical significance were expressed as ${ }^{*} p<0.05$ and ${ }^{* *} p<0.01$ level (Aldrich, 2018; Ozturk et al., 2019).

\section{Results and Discussion}

The results of analysis of plant samples are presented in Table 1. The nutrient concentrations measured in the plant samples of different localities ranged from $0.82-0.99 \%$ for nitrogen, $0.07-0.09 \%$ for phosphorus, $0.6-0.8 \%$ for potassium, $0.52-0.63 \%$ for calcium, $0.23-0.30 \%$ for magnesium, $145-620 \mathrm{mg}$ $\mathrm{kg}^{-1}$ for aluminium, $0.0-1.5 \mathrm{mg} \mathrm{kg}^{-1}$ for cobalt, $1.5-4.5 \mathrm{mg} \mathrm{kg}^{-1}$ for copper, $70-230 \mathrm{mg} \mathrm{kg}^{-1}$ for iron, $3-15 \mathrm{mg} \mathrm{kg}^{-1}$ for lead, $3.5-6.0 \mathrm{mg}$ $\mathrm{kg}^{-1}$ for nickel, and $18-37 \mathrm{mg} \mathrm{kg}^{-1}$ for zinc, respectively. Cadmium was not present in any plant sample (Table 1). In the soil, the concentrations of nitrogen, phosphorus, potassium, calcium, magnesium, copper, iron, and nickel varied between 0 and $0.003 \%, 0.11$ and $0.18 \%, 0.003$ and $0.006 \%, 0$ and $1.08 \%, 0$ and $0.011 \%, 0$ and $1.49 \mathrm{mg} \mathrm{kg}^{-1}, 11.2$ and $30.8 \mathrm{mg} \mathrm{kg}^{-1}$ and $2.06 \mathrm{mg} \mathrm{kg}^{-}$ ${ }^{1}$, respectively (Table 2 ).

In general, the plant samples collected from the study areas were rich in iron, aluminium, zinc and nickel; however, the percentages of these elements in the soils were low. The results of soil analyses are presented in Table 2. The mean values of soil samples revealed that $E$. gaultherioides prefers soils with sandy and / or clayey texture, strongly acidic in nature, non-calcified, non-saline but rich in organic matter. 
Table 1: Concentrations of some major and trace elements in plant samples of different locations

\begin{tabular}{|c|c|c|c|c|c|}
\hline Plant samples & Location 1 & Location 2 & Location 3 & Location 4 & Location 5 \\
\hline $\mathrm{N}(\%)$ & 0.82 & 0.82 & 0.99 & 0.93 & 0.96 \\
\hline $\mathrm{P}(\%)$ & 0.08 & 0.07 & 0.07 & 0.09 & 0.09 \\
\hline $\mathrm{K}(\%)$ & 0.6 & 0.6 & 0.7 & 0.7 & 0.8 \\
\hline $\mathrm{Ca}(\%)$ & 0.63 & 0.58 & 0.52 & 0.59 & 0.53 \\
\hline $\mathrm{Mg}(\%)$ & 0.29 & 0.30 & 0.26 & 0.23 & 0.29 \\
\hline $\mathrm{Fe}\left(\mathrm{mg} \mathrm{kg}^{-1}\right)$ & 150 & 70 & 135 & 230 & 120 \\
\hline $\mathrm{Cu}\left(\mathrm{mg} \mathrm{kg}^{-1}\right)$ & 2.5 & 1.5 & 4.5 & 3.5 & 4.5 \\
\hline $\mathrm{Ni}\left(\mathrm{mg} \mathrm{kg}^{-1}\right)$ & 5.5 & 5.5 & 3.5 & 6.0 & 5.5 \\
\hline $\mathrm{Cd}\left(\mathrm{mg} \mathrm{kg}^{-1}\right)$ & 0 & 0 & 0 & 0 & 0 \\
\hline $\mathrm{Zn}\left(\mathrm{mg} \mathrm{kg}^{-1}\right)$ & 18 & 18 & 29 & 24 & 37 \\
\hline $\mathrm{Pb}\left(\mathrm{mg} \mathrm{kg}^{-1}\right)$ & 12 & 6 & 15 & 3 & 8 \\
\hline $\mathrm{Co}\left(\mathrm{mg} \mathrm{kg}^{-1}\right)$ & 1.0 & 1.5 & 1.5 & 0.5 & 0.0 \\
\hline $\mathrm{Al}\left(\mathrm{mg} \mathrm{kg}^{-1}\right)$ & 205 & 235 & 275 & 145 & 620 \\
\hline
\end{tabular}

Table 2 : Physical and chemical parameters in soil samples of different locations

\begin{tabular}{llllll}
\hline Soil samples & Location 1 & Location 2 & Location 3 & Location 4 & Location 5 \\
\hline Sand $(\%)$ & 78.55 & 90.81 & 74.10 & 78.66 & 73.77 \\
Clay $(\%)$ & 7.07 & 4.02 & 11.33 & 7.01 & 9.36 \\
Silt $(\%)$ & 14.38 & 5.18 & 14.58 & 14.26 & 16.87 \\
$\mathrm{pH}$ & 4.7 & 4.9 & 5.0 & 5.5 & 5.6 \\
Organic matter $(\%)$ & 1.60 & 21.76 & 3.79 & 4.42 & 2.38 \\
$\mathrm{CaCO}(\%)$ & 0 & 0 & 0 & 0 & 0 \\
$\mathrm{Na}\left(\mathrm{mg} \mathrm{kg}^{-1}\right)$ & 20.03 & 15.18 & 22.72 & 15.09 & 0 \\
$\mathrm{~N}(\%)$ & 0.003 & 0.002 & 0 & 0 & 0.18 \\
$\mathrm{P}(\%)$ & 0.11 & 0.003 & 0.12 & 0.17 & 0.003 \\
$\mathrm{~K}(\%)$ & 0.006 & 0.02 & 0.004 & 0 & 0.07 \\
$\mathrm{Ca}(\%)$ & 1.08 & 0.001 & 0.09 & 0.002 & 0 \\
$\mathrm{Mg}(\%)$ & 0.011 & 11.2 & 0.001 & 22.4 & 30.8 \\
$\mathrm{Fe}\left(\mathrm{mg} \mathrm{kg}^{-1}\right)$ & 25.2 & 0.00 & 28.0 & 0.00 & 1.49 \\
$\mathrm{Cu}\left(\mathrm{mg} \mathrm{kg}^{-1}\right)$ & 0.44 & 2.06 & 0.00 & 2.06 & 2.06 \\
$\mathrm{Ni}\left(\mathrm{mg} \mathrm{kg}{ }^{-1}\right)$ & 2.06 & & 2.06 & & \\
\hline
\end{tabular}

The correlation coefficients between the elemental values determined in the plant samples from different altitudes (Table 3 ) showed positive significant correlation between zinc and available potassium as well as copper $(>0.97,>0.89)$. High positive significant correlations were found between the available copper and nitrogen $(>0.95)$. However, highly negative significant correlations were found between the available of cobalt and phosphorus (->0.96).

The correlation coefficients between the elemental values determined in the soil samples from different altitudes (Table 4) showed that positive significant correlation existed between magnesium and available of potassium as well as calcium $(>0.93,>0.98)$. High positive significant correlations were found between the available of organic matter and sand $(>0.93)$; between available iron and clay $(>0.88)$; iron and silt $(>0.97)$; phosphorus and $\mathrm{pH}(>0.99)$; and finally between available calcium and potassium $(>0.96)$. However, highly significant negative correlations were found between sand and available clay, silt and iron (->0.91, ->0.97, ->0.99), between organic matter and available of silt and iron $(->0.97,->0.92)$.

The correlation coefficients between the elemental values determined in the plant and soil samples from different altitudes (Table 5) showed that positive significant correlation existed between plant $\mathrm{Cu}$ and available of soil Fe $(>0.88)$. However, highly significant negative correlations were found between plant $\mathrm{N}$ and available soil $\mathrm{N}(->0.93)$.

Habitat loss is the major factor for biodiversity loss which leads towards species extinction. The basis for conservation is the investigation of ecology and distribution of species. Many endemic and/or relict taxa show restricted distribution. This is one of the major topics of several ecological and phylogenetic researches (Ozturk et al., 2004). Nearly 25 to 100 species are lost everyday as a result of habitat loss, alien species introductions, over exploitation of species and environmental pollution. Extinction of taxa is proceeding at such a high rate that our 
Table 3 : Pearson's correlation coefficients of major and trace elements in plant samples in different locations

\begin{tabular}{|c|c|c|c|c|c|c|c|c|c|c|c|c|}
\hline \multicolumn{13}{|l|}{ Correlation matrix (R) } \\
\hline & $\mathbf{P}$ & $\mathrm{K}$ & $\mathrm{Ca}$ & $\mathrm{Mg}$ & $\mathrm{Fe}$ & $\mathrm{Cu}$ & $\mathrm{Ni}$ & $\mathrm{Cd}$ & $\mathrm{Zn}$ & $\mathrm{Pb}$ & Co & Al \\
\hline $\mathrm{N}$ & 0.251 & 0.841 & -0.826 & -0.543 & 0.315 & $0.950^{*}$ & -0.513 & .0 .115 & 0.846 & 0.200 & -0.328 & 0.423 \\
\hline $\mathbf{P}$ & & 0.598 & 0.110 & -0.347 & 0.624 & 0.383 & 0.641 & .0 .078 & 0.435 & -0.525 & $-0.959^{*}$ & 0.340 \\
\hline $\mathrm{K}$ & & & -0.726 & -0.270 & 0.211 & 0.871 & -0.092 & .0 .053 & $0.973^{* *}$ & -0.075 & -0.733 & 0.760 \\
\hline $\mathrm{Ca}$ & & & & 0.077 & 0.261 & -0.720 & 0.623 & .0 .084 & -0.817 & -0.267 & 0.085 & -0.619 \\
\hline $\mathrm{Mg}$ & & & & & -0.876 & -0.439 & 0.053 & .0 .193 & -0.123 & 0.244 & 0.160 & 0.421 \\
\hline $\mathrm{Fe}$ & & & & & & 0.350 & 0.249 & .0 .026 & 0.037 & -0.279 & -0.409 & -0.381 \\
\hline $\mathrm{Cu}$ & & & & & & & -0.452 & .0 .204 & $0.887^{*}$ & 0.314 & -0.471 & 0.528 \\
\hline $\mathrm{Ni}$ & & & & & & & & .0 .261 & -0.261 & -0.824 & -0.551 & -0.046 \\
\hline $\mathrm{Cd}$ & & & & & & & & & .0 .301 & .0 .273 & .0 .066 & .0 .088 \\
\hline $\mathrm{Zn}$ & & & & & & & & & & 0.119 & -0.615 & 0.833 \\
\hline $\mathrm{Pb}$ & & & & & & & & & & & 0.435 & 0.103 \\
\hline Co & & & & & & & & & & & & -0.593 \\
\hline
\end{tabular}

"Correlation is significant at 0.01 level (2-tailed); "Correlation is significant at 0.05 level (2-tailed)

Table 4 : Pearson's correlation coefficients of major and trace elements in soil samples in different locations

\begin{tabular}{|c|c|c|c|c|c|c|c|c|c|c|c|c|c|}
\hline \multicolumn{14}{|c|}{ Correlation matrix (R) } \\
\hline & Clay & Silt & $\mathrm{pH}$ & OM & $\mathrm{Na}$ & N & $\mathbf{P}$ & K & $\mathrm{Ca}$ & $\mathrm{Mg}$ & $\mathrm{Fe}$ & $\mathrm{Cu}$ & $\mathrm{Ni}$ \\
\hline Sand & $-0.913^{*}$ & $-0.970^{* *}$ & -0.414 & $0.933^{*}$ & -0.728 & 0.547 & -0.384 & -0.193 & -0.100 & -0.011 & $-0.985^{* *}$ & -0.467 & .0 .036 \\
\hline Clay & & 0.785 & 0.271 & -0.735 & 0.724 & -0.612 & 0.184 & 0.105 & -0.075 & -0.185 & $0.881^{*}$ & 0.293 & .0 .049 \\
\hline Silt & & & 0.463 & $-0.974^{* *}$ & 0.673 & -0.459 & 0.470 & 0.233 & 0.200 & 0.130 & $0.966^{\star *}$ & 0.536 & .0 .093 \\
\hline $\mathrm{pH}$ & & & & -0.285 & 0.334 & -0.813 & $0.986^{* *}$ & -0.716 & -0.634 & -0.635 & 0.383 & 0.487 & .0 .070 \\
\hline OM & & & & & -0.558 & 0.301 & -0.303 & -0.422 & -0.375 & -0.326 & $-0.924^{*}$ & -0.406 & .0 .162 \\
\hline $\mathrm{Na}$ & & & & & & -0.349 & 0.324 & 0.051 & 0.035 & -0.161 & 0.816 & 0.835 & .0 .205 \\
\hline N & & & & & & & -0.709 & 0.678 & 0.769 & 0.781 & -0.458 & -0.167 & .0 .308 \\
\hline$P$ & & & & & & & & -0.651 & -0.528 & -0.528 & 0.371 & 0.554 & .0 .218 \\
\hline K & & & & & & & & & $0.959^{* *}$ & $0.932^{*}$ & 0.241 & -0.066 & .0 .316 \\
\hline $\mathrm{Ca}$ & & & & & & & & & & $0.976^{* *}$ & 0.177 & 0.078 & .0 .082 \\
\hline $\mathrm{Mg}$ & & & & & & & & & & & 0.061 & -0.081 & .0 .064 \\
\hline $\mathrm{Fe}$ & & & & & & & & & & & & 0.593 & .0 .028 \\
\hline $\mathrm{Cu}$ & & & & & & & & & & & & & .0 .227 \\
\hline
\end{tabular}

"Correlation is significant at 0.01 level (2-tailed); "Correlation is significant at 0.05 level (2-tailed); OM: Organic matter

coming generations will face serious consequences if steps are not taken today.

A great emphasis has been laid on the conservation of relict taxa and populations (Habel et al., 2010a; Hampe and Petit, 2005; Vogler and Reisch, 2013). The reason has being their evolutionary significance. Such populations sharing our planet today have existed successfully under severe ecological stresses for long durations (Ronikier et al., 2012; Vogler and Reisch, 2013). In view of this, they have got adapted to their harsh environment, mostly located at the edge of their distribution range and are exposed to strong selection processes. Therefore, relict taxa may be the best examples to challenge future climatic changes (Habel et al., 2010b; Vogler and Reisch, 2013). These plant taxa are natural laboratories fitting the models for testing how natural plant populations will respond to climate change
(Hampe and Petit, 2005; Lázaro-Nogal et al., 2016). Their antiquity renders them important for the conservation of genetic diversity (Hampe and Petit, 2005; Hampe and Jump, 2011; Lázaro-Nogal et al., 2016). The relicts; in particular when these are also endemics; are of great importance from the point of view of conservation biology as they can be highly informative for knowing the past diversity and have a high patrimonial value (Grandcolas et al., 2014). The relicts are more informative in terms of diversity of todays groups than their original ancestral characters. Their importance would increase more during the coming decades because of the major extinction crisis currently under way. Latter will make it necessary to conserve species not only for ecological services but also as representatives of a patrimony nested in the Tree of Life. Relicts include valuable taxa, clading extinctions and need conservation as representatives of large and mainly extinct groups (Grandcolas et al., 2014). 
Table 5 : Pearson's correlation coefficients of major and trace elements in plant and soil samples in different locations

\begin{tabular}{|c|c|c|c|c|c|c|c|c|}
\hline \multicolumn{9}{|c|}{ Correlation Matrix (R) } \\
\hline & Plant N & Plant P & Plant K & Plant Ca & Plant Mg & PlantFe & Plant Cu & Plant Ni \\
\hline Soil N & $-0.933^{*}$ & -0.354 & -0.845 & 0.781 & 0.614 & -0.350 & -0.813 & 0.272 \\
\hline Soil P & 0.533 & 0.849 & 0.830 & -0.341 & -0.375 & 0.411 & 0.533 & 0.435 \\
\hline Soil K & -0.400 & -0.192 & -0.504 & 0.551 & 0.226 & 0.069 & -0.176 & -0.157 \\
\hline Soil Ca & -0.546 & -0.022 & -0.501 & 0.686 & 0.330 & 0.058 & -0.292 & 0.109 \\
\hline Soil Mg & -0.604 & 0.002 & -0.594 & 0.805 & 0.192 & 0.190 & -0.381 & 0.198 \\
\hline Soil Fe & 0.688 & 0.463 & 0.708 & -0.409 & -0.218 & 0.347 & $0.880^{*}$ & -0.323 \\
\hline Soil Cu & 0.226 & 0.577 & 0.664 & -0.284 & 0.415 & -0.182 & 0.426 & 0.230 \\
\hline Soil Ni & .0 .303 & .0 .155 & .0 .222 & .0 .099 & .0 .106 & .0 .037 & .0 .052 & .0 .091 \\
\hline
\end{tabular}

"Correlation is significant at 0.01 level (2-tailed); "Correlation is significant at 0.05 level (2-tailed)

In order to secure the survival of threatened relicts, international coordination among the scientists needs to be significantly improved (Kozlowski et al., 2012). For this purpose, living ex-situ collections will be an ideal solution as a part of overall conservation strategies. It must also include participation by local administration, national parks, foresters together with other ex-situ and in-situ approaches for successful conservation (Kozlowski et al., 2012).

Kozlowski et al. (2012) have presented some recommendations for relict plants conservation via living ex-situ collections:

1. Prepare a global priority list of most important relict taxa with their global conservation status; 2. "Botanic Gardens" and "Arboreta" in the countries with emblematic relict taxa in particular woody ones should integrate their ex-situ conservation into their conservation strategies and action plans. They need to develope their public awareness and outreach programmes, particularly in the regions where such woody species are most at threat; 3 . Conservation priority should be given to the most threatened taxa, rare and/or to narrow endemics in the case of relict genera; 4. Involvement of local communities and organisations is a must and critical for long term conservation of such taxa. This needs to be encouraged and supported from the earliest stages of conservation planning; 5 . In the case of new ex-situ collections only well-documented plant material with detailed information on its origin should be used; 6 . Detailed investigations of the provenance data for all relict plants in cultivation should be undertaken in the case of existing, often very old collections; 7. Genetic studies at genus level should be carried out for verifying and/or clarifying of provenance of ex situ collections of threatened relict woody plants in cultivation; 8. Conservation of maximum genetic diversity for a given taxon should be undertaken concerning the minimum number of cultivated woody plants per botanic garden; 9 . Well-coordinated specialist groups should be established for highly threatened relict woody species and/or genera, so as to act globally and to develop their long term ex-situ conservation strategy.
Epigaea gaultherioides, Liquidambar orientalis, Quercus pontica and other relict plants are ecologically important for Turkish relict diversity. They need special attention from the point of biodiversity as well as for the global diversity as a relict heritage with us from tertiary period. We must protect their current distribution area as much as we can.

\section{References}

Aguilar, R., M. Quesada, L. Ashworth, Y. Herrerias-Diego and J. Lobo: Genetic consequences of habitat fragmentation in plant populations: Susceptible signals in plant traits and methodological approaches. Mol. Ecol., 17, 5177-5188 (2008).

Aldrich, J.O.: Using IBM $\circledast$ SPSS $\circledast$ Statistics: An interactive hands-on approach. Sage Publications (2018).

Davis, P.H.: Flora of Turkey and the East Aegean Islands. Vol. VI, Edinburgh: Edinburgh University Press (1978).

Denk, T., N. Frotzler and N. Davitashvili: Vegetational patterns and distribution of relict taxa in humid temperate forests and wetlands of Georgia (Transcaucasia). Biol. J. Linn. Soc., 72, 287-332 (2001).

El-Bana, M., K. Shaltout, A. Khalafallah and H. Mosallam: Ecological status of the Mediterranean Juniperus phoenicea L. relicts in the desert mountains of North Sinai, Egypt. Flora-Morphol. Distrib. Funct. Ecol. Plants, 205, 171-178 (2010).

Gillespie, E.L. and K.A. Kron: Molecular phylogenetic relationships and morphological evolution within the tribe Phyllodoceae (Ericoideae, Ericaceae). Syste. Bot., 38, 752-763 (2013).

Grandcolas, P., R. Nattier and S. Trewick: Relict species: A relict concept? Trends in Ecol. Evol., 29, 655-663 (2014).

Habel, J.C., T. Assmann, T. Schmitt and J.C. Avise: Relict species: From past to future. In: Relict species. Phylogeography and conservation biology (Eds.: J.C. Habel and T. Assmann). Springer, Heidelberg, Dordrecht, London, New York, pp. 1-5 (2010a).

Habel, J.C., T. Schmitt and T. Assmann: Relict species research: some concluding remarks. In: Relict species. Phylogeography and Conservation Biology (Eds.: J.C. Habel and T. Assmann), Springer, Heidelberg, Dordrecht, London, New York, pp. 441-442 (2010b).

Hampe, A. and A.S. Jump: Climate relicts: Past, present, future. Annu. Rev. Ecol. Evol. Syst., 42, 313-333 (2011).

Hampe, A. and R.J. Petit: Conserving biodiversity under climate change: 
the rear edge matters. Ecol. Lett., 8, 461-467 (2005).

Huenneke, L.F.: Ecological implications of genetic variation in plant populations. In: Genetics and conservation of rare plants (Eds.: D.A. Falk and K.E. Holsinger). Oxford University Press, Oxford, pp. 31-44 (1991).

Kozlowski, G., D. Gibbs, F. Huan, D. Frey and J. Gratzfeld: Conservation of threatened relict trees through living ex-situ collections: Lessons from the global survey of the genus Zelkova (Ulmaceae). Biodiversity and Conservation, 21, 671-685 (2012).

Lázaro-Nogal, A., S. Matesanz, L. Hallik, A. Krasnova, A. Traveset and F. Valladares: Population differentiation in a Mediterranean relict shrub: The potential role of local adaptation for coping with climate change. Oecologia, 180, 1075-1090 (2016).

Mai, D.H.: Tertiare Vegetations geschichte Europas. Jena: Gustav Fischer Verlag (1995).

Ozturk, M., M. Pirdal and F. Ozdemir: Plant Ecology Applications. Ege Univ. Science Fac., Ege Univ. Press, Izmir, Turkey (1997).

Ozturk, M., C.R. Parks, F. Coskun, G. Gork and O. Secmen: Vanishing tertiary genetic heritage in the East Mediterranean, Liquidambar orientalis Mill. Environews, 10, 6-8 (2004).

Ozturk, M., I. Uysal, E. Yucel, V. Altay and E. Karabacak: Soil-plant interactions in the monumental plane trees (Platanus orientalis) grove-Canakkale-Turkey. J. Environ. Biol., 38, 1129-1137 (2017).

Ozturk, M., V. Altay, M. Kucuk and I.E. Yalçın: Trace elements in the soil- plant systems of copper mine areas - A case study from Murgul Copper Mine from the Black Sea Region of Turkey. Phyton-Inter. J. Experi. Bot., 88, 223-238 (2019).

Pott, R.: The origin of grassland plant species and grassland communities in Central Europe. Fitosociologia (Padua), 29, 7-32 (1995).

Ronikier, M., G.M. Schneeweis and P. Schönswetter: The extreme disjunction between Beringia and Europe in Ranunculus glacialis (Ranunculaceae) does not coincide with the deepest genetic splita story of the importance of temperate mountain ranges in arcticalpine phylogeography. Molecular Ecology, 21, 5561-5578 (2012).

Serdar, B., S. Terzioglu, N. Merev, Z. Gercek and T. Birtürk: Woody anatomy of four dwarf shrub species of Ericaceae in Turkey: Ecological and phyletic aspects. Frese. Environ. Bull., 19, 22392246 (2010).

Šmídová, A., Z. Münzbergová and I. Plačková: Genetic diversity of a relict plant species, Ligularia sibirica (L.) Cass. (Asteraceae). Flora-Morphol, Distrib., Funct. Ecol. Plants, 206, 151-157 (2011).

Vogler, F. and C. Reisch: Vital survivors: low genetic variation but high germination in glacial relict populations of the typical rock plant Draba aizoides. Biodiver. Conse., 22, 1301-1316 (2013).

Wei, $X$. and M. Jiang: Limited genetic impacts of habitat fragmentation in an "old rare" relict tree, Euptelea pleiospermum Eupteleaceae). PlantEcology, 213, 909-917 (2012). 